\title{
The CRISIS of THEORY
}

\section{EP Thompson, the new left and postwar British politics}

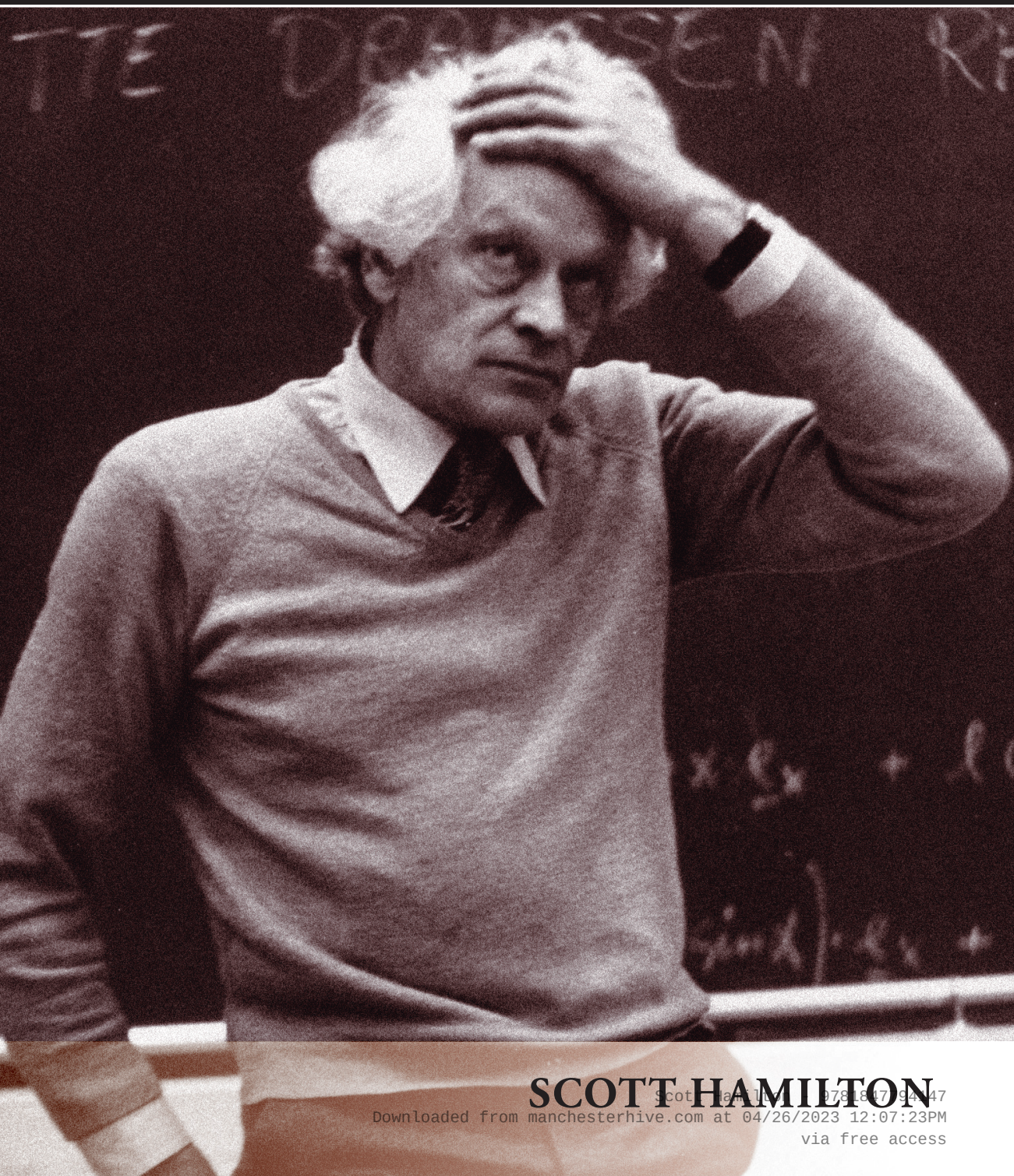




\section{The crisis of theory}

\section{MANCHESTER 1824}

Manchester University Press 
Scott Hamilton - 9781847794147 Downloaded from manchesterhive.com at $04 / 26 / 2023$ 12:07:23PM 


\title{
The crisis of theory EP Thompson, the New Left and postwar British politics
}

\author{
SCOTT HAMILTON
}

Manchester University Press

Manchester 
Copyright $\odot$ Scott Hamilton 2011

The right of Scott Hamilton to be identified as the author of this work has been asserted by him in accordance with the Copyright, Designs and Patents Act 1988.

Published by Manchester University Press

Altrincham Street, Manchester M1 7JA, UK

www.manchesteruniversitypress.co.uk

British Library Cataloguing-in-Publication Data is available

Library of Congress Cataloging-in-Publication Data is available

ISBN 9780719089091 paperback

First published by Manchester University Press in hardback 2011

The publisher has no responsibility for the persistence or accuracy of URLs for any external or thirdparty internet websites referred to in this book, and does not guarantee that any content on such websites is, or will remain, accurate or appropriate. 